\title{
Strength Development and Physical Properties of Cement Paste with Incorporated Ceramic Powder
}

\author{
Tereza KULOVANÁ*, Jaroslav POKORNÝ, Martin KEPPERT, Zbyšek PAVLÍK, \\ Robert ČERNÝ
}

\author{
Czech Technical University in Prague, Faculty of Civil Engineering, Department of Materials Engineering and Chemistry, \\ Thákurova 7, 16629 Prague 6, Czech Republic
}

cross $^{\text {ref }}$ http://dx.doi.org/10.5755/j01.ms.22.1.7190

Received 26 May 2014; accepted 17 July 2015

\begin{abstract}
A possible usage of fine waste ceramic powder coming from precise brick cutting in production of blended cement is analyzed in the paper. For the studied ceramic powder, chemical and mineralogical composition is measured by X-Ray Fluorescence and X-Ray Diffraction. The particle size distribution of ceramic powder is accessed on laser diffraction principle. The ceramic powder is used in cement based pastes composition in cement mass replacements of 8, 16, 24, 32, and $40 \%$. For the tested pastes, monitoring of strength development is done using measurement of time dependent mechanical parameters. Bulk density, matrix density, and total open porosity are measured for 28 days cured samples. In order to obtain information on the rate of hydration process, the formation of pastes' solid structure is monitored using measurement of pore size distribution at chosen times of hydration. Application of waste ceramics is found to give the most promising mechanical properties of the cement-based paste for 8 and $16 \%$ cement replacement levels what makes good prerequisites for future research that will be focused on design and development of new types of cement-based composites with incorporated ceramic waste powder. However, also other tested mixtures provide acceptable results. This knowledge can be used for instance in the production of lower strength composites.

Keywords: ceramic powder, partial cement replacement, cement paste, strength development, porosity, pore size distribution.
\end{abstract}

\section{INTRODUCTION}

Concrete is beyond question the most important building material. Besides the concrete excellent mechanical and durability properties that are the main reasons for its usage, its production brings several harmful secondary effects to the human society. Especially the cement production has high negative impact on the quality of environment, and its sustainability is open question for material researchers and producers. Worldwide, the cement industry alone is estimated to be responsible for about $7 \%$ of all $\mathrm{CO}_{2}$ generated [1,2]. Additionally, the cement production requires high energy impact, which is approximately $850 \mathrm{kcal}$ per $\mathrm{kg}$ of clinker [3]. To ensure the future competitiveness of concrete as a building material, it is essential to improve the sustainability of concrete structures. Therefore, the replacement of cement in concrete by any type of industrial waste represents a tremendous saving of energy and has important environmental benefits [4-6].

Several by-products have already found their utilization in concrete production. Incorporations of coal combustion fly ash (CFA), ground granulated blast furnace slag (GBFS), and silica fume (SF) are typical examples of reuse of industrial by-products in concrete manufacturing. CFA is probably the most widely used cement supplementary material in concrete industry, being an important pozzolan, which has a number of advantages compared with regular Portland cement. Blended cements

\footnotetext{
* Corresponding author. Tel.: +420 224354 771; fax: +420 224354446. E-mail address: tereza.kulovana@fsv.cvut.cz (T. Kulovana)
}

containing CFA have lower heat of hydration compared to Portland cement and moreover, concrete produced with CFA can have better strength and durability than concrete produced without it [7]. Concrete with incorporated CFA has lower permeability to chloride ions and other aggressive environments [8], higher freeze-thaw resistance and abrasion resistance [9]. Also GBFS improves positively properties of concrete, especially its mechanical properties and rheology of fresh mixtures even in high volume applications [10]. Here, the resistance to frost cycles, sulphates and chlorides can also be improved using the GBFS as partial cement replacement in blended binder. $\mathrm{SF}$ as a by-product of induction arc furnaces in production silicon metal or ferrosilicon alloys has long been used as a mineral admixture to produce high-strength and highperformance concrete. However, besides the above given materials that are generally accepted in concrete production, also other type of wastes should be characterised and studied for their reuse in concrete mix design.

In this paper, a possible usage of waste ceramics in concrete production is analyzed. In Europe, the amount of wastes in the different production stages of the ceramic industry reaches some $3-7 \%$ of its global production meaning millions of tons of calcined-clays per year that are just land filled [11]. Because of the worldwide ceramic industry, high amount of waste ceramics is produced annually over the world. Although the reutilization of ceramic wastes has been practiced, the amount of wastes reused in that way is still negligible and most of the ceramic waste is landfilled. A portion of ceramic products 
formed within the burning illite-group minerals and having suitable fineness can become active pozzolans [12]. Therefore, waste ceramic materials may have a potential to become a cheaper, but almost equivalent, alternative to metakaolin as supplementary binder in mortars, concretes and other types of cement based composites. Application of waste ceramics in concrete production would lead to reduction of cost and energy demands, promoting ecological balance and conservation of natural resources. Looking at literature, several authors already proved the great potential of waste ceramic powders to be used as partial cement replacement. However, specific attention must be always paid to chemical and mineralogical compositions of waste ceramics, whose properties are highly dependent on raw materials used for its production. On this account, every waste ceramic material must be studied in detail and its applicability in blended binders verified. Here, the fine ceramic powder coming from one of the Czech brick factories is researched as possible mineral admixture in cement based composite mix design.

\section{STUDIED MATERIALS, SAMPLING}

Ceramic powder is a by-product of brick company HELUZ Brick Industry that is the second biggest producer and deliverer of the brick material on the Czech market. The ceramic powder is produced within the cutting highly precise cavity brick blocks that are manufactured in width from $250 \mathrm{~mm}$ to $500 \mathrm{~mm}$. The company has production facilities in three locations. The ceramic waste used in this work is coming from the production plant Dolní Bukovsko, located in the southern part of the Czech Republic.

For the preparation of blended binders with incorporated ceramic waste powder, ordinary Portland cement (CEM I 42.5 R) was used. Ceramic powder in the blended binders replaced 8, 16, 24, 32 and $40 \%$ of cement by mass. The water/binder ratio in all prepared cement pastes was 0.5 . With a view to the evaluation of the ceramic powder effect on the paste performance, also a reference mixture with Portland cement as the only binder was studied. For the mechanical parameters assessment, the fresh mixtures were cast into the moulds having the dimensions of $40 \times 40 \times 160 \mathrm{~mm}$. Basic physical properties were measured on cubes of side $50 \mathrm{~mm}$. After 24 hours, the samples were unmoulded and left in water. The measurement of mechanical properties was realised in dependence on hydration time, nominally for 1 day, 2 days, 7 days and 28 days of wet curing. Development of porous structure was monitored on 1, 7 and 28 days cured samples. Basic physical properties were measured for 28 days cured samples.

\section{EXPERIMENTAL}

Chemical and mineralogical composition of researched ceramic powder was determined by X-Ray Fluorescence (XRF) and X-Ray Diffraction (XRD) analysis. X-Ray diffractograms were measured with a diffractometer PANalytical X'PertPRO (PANalytical, Almelo) with Bragg-Brentano configuration (CoK $\alpha$ radiation source, voltage of $40 \mathrm{kV}$ at $30 \mathrm{~mA}$ ) and fast linear detector $\mathrm{X}^{\prime}$ Celerator. Measured diffractograms were analysed by the computer code HighScorePlus 3.0.5 (PANalytical,
Almelo), comparing with the database data from JCPDS PDF2, Sets 1-54 (International Centre for Diffraction Data, Newton Square, Pennsylvania). The amount of the particular crystalline phases was determined by the Rietveld method using the code DiffracPlus Topas 4.2. Here, models obtained from database ICSD, release 2012/1 (FIZ Karlsruhe, SRN) and American Mineralogist Crystal Structure Database were used. The amorphous fraction was found by the method of standard addition, with $\mathrm{ZnO}$ in an amount of $10 \%$ of mass of the sample.

For the ceramic powder, cement and blended binders with partial cement replacement by ceramics, particle size distribution was measured. The measurement was done on laser diffraction principle using the device Analysette 22 MicroTec plus (FRITSCH). It allows measurement of particle size in the range of $0.08-2000 \mu \mathrm{m}$. The measuring range is obtained with the utilization of two lasers with different wavelength. A green laser is used for the small particle range whereas an IR-laser is utilized for the measurement of larger particles.

Among the basic physical properties, bulk density, matrix density and total open porosity were measured. The experiments were done on 5 cubic samples of side $50 \mathrm{~mm}$. The relative expanded uncertainty of applied testing method was expected $5 \%$. Bulk density was determined from the measurement of sample sizes (using digital length meter) and its dry mass. The matrix density was accessed by helium pycnometry using Pycnomatic ATC (Thermo Scientific). On the basis of bulk density and matrix density measurements, the total open porosity values were calculated [13, 14].

Bending and compressive strength of tested pastes with incorporated brick powder were measured in several time steps of hydration, respectively for 1 day, 2 days, 7 days and 28 days cured samples. The bending strength of hardened mortars was determined using the procedure described in the standard ČSN EN 12390-5. For the measurement, prismatic samples having dimensions of $160 \times 40 \times 40 \mathrm{~mm}$ were used. The compressive strength was measured according to the standard CSN EN 12390-3 on the portions of prisms broken in the bending test; the loading area was $40 \times 40 \mathrm{~mm}$.

In order to obtain information on the rate of hydration process, the formation of pastes' solid structure was monitored using measurement of pore size distribution. These experiments were done on mercury intrusion porosimetry principle using Pascal porosimeters (Thermo Scientific). The Pascal 140 has a dual role: it prepares the sample for the analysis and carries out low pressure porosimetry from vacuum up to $400 \mathrm{KPa}$, measuring very large pores and particles (pore size diameter 116-3.8 $\mu \mathrm{m}$ ). In our experiments it is coupled with high pressure modul Pascal 440 that reaches the pressures of $400 \mathrm{MPa}$, which enables very small pores to be measured (pore size diameter $15-0.0036 \mu \mathrm{m}$ ). At the evaluation of measured data, the circular cross section of capillaries was assumed.

\section{RESULTS AND DISCUSSION}

Chemical composition of analysed ceramic powder measured by XRF is given in Table 1. Here, only the main observed oxides are given since other compounds were 
contained in trace amounts only. Mineralogical composition of studied ceramics, as accessed by XRD analysis, is given in Table 2 . The amorphous content measured by XRD is 28.5 mass \% only. Although the chemical composition meets requirement of high silica amount, low content of amorphous fraction does not give good presumption for pozzolanic performance of analysed ceramic powder.

Table 1. Chemical composition of ceramic powder

\begin{tabular}{|c|c|c|}
\hline Substance & $\begin{array}{c}\text { Amount, } \\
\text { mass } \%\end{array}$ & $\begin{array}{c}\text { Amount of amorphous phase, } \\
\text { mass \% }\end{array}$ \\
\hline $\mathrm{SiO}_{2}$ & 63.5 & 13.0 \\
\hline $\mathrm{Al}_{2} \mathrm{O}_{3}$ & 20.4 & 53.1 \\
\hline $\mathrm{Fe}_{2} \mathrm{O}_{3}$ & 4.8 & 6.3 \\
\hline $\mathrm{CaO}$ & 4.2 & 14.1 \\
\hline $\mathrm{MgO}$ & 1.8 & 6.0 \\
\hline $\mathrm{K}_{2} \mathrm{O}$ & 2.5 & 2.5 \\
\hline $\mathrm{Na}_{2} \mathrm{O}$ & 1.1 & 0.0 \\
\hline $\mathrm{TiO}_{2}$ & 0.8 & 3.0 \\
\hline $\mathrm{SO}_{3}$ & 0.5 & 2.0 \\
\hline$\sum$ & 99.6 & 100 \\
\hline
\end{tabular}

Table 2. Mineralogical composition of ceramic powder

\begin{tabular}{|c|c|}
\hline Mineral & Amount, mass \% \\
\hline Quartz & 44.8 \\
\hline Hematite & 3.0 \\
\hline Albite & 11.9 \\
\hline Muscovite & 4.0 \\
\hline Microcline & 7.8 \\
\hline$\sum$ & 71.5 \\
\hline
\end{tabular}

Particle size distribution measured by laser diffraction is presented in Fig. 1. The studied ceramic powder was slightly coarser compared to the cement. However, one must take into account that the ceramic powder was taken directly from the brick factory without any additional milling. Therefore, the fineness of studied pozzolan can be considered as good in general.

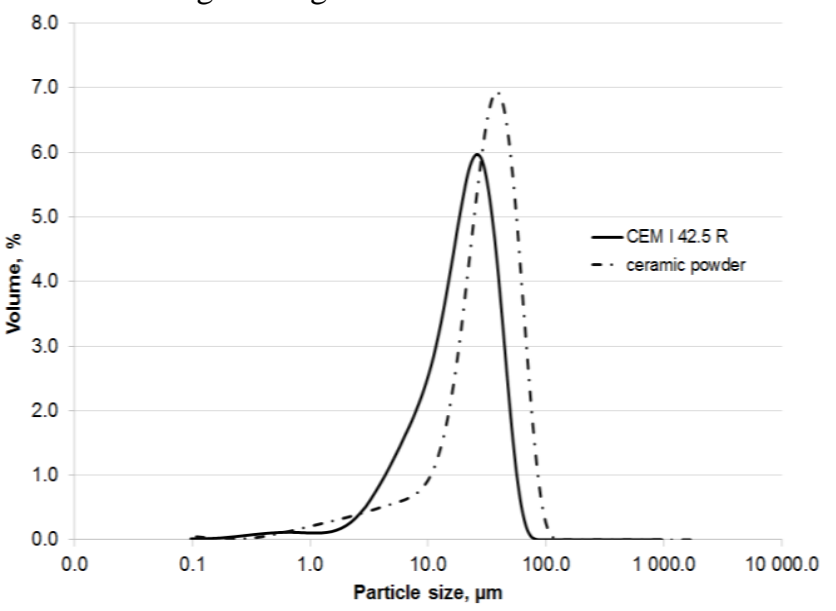

Fig. 1. Particle size distribution - distribution curve

Compressive and bending strength data is presented for specific measured times of hydration in Table 3-Table 6. Here, the reference paste is denoted Pref and other pastes with ceramic powder are denoted according to the amount of pozzolan used.

Also the data on strength activity index (SAI) is given, although its minimum value is recommended according to ASTM C618-02 [15] for pozzolan testing applied in cement based mortars only. SAI is in ASTM C311 [16] defined as $\mathrm{SAI}=(\mathrm{A} / \mathrm{B}) \times 100$, where $\mathrm{A}=$ average compressive strength of blended cement mortar samples, $\mathrm{B}=$ average compressive strength of control mortar samples. The time dependent mechanical properties are graphically displayed in Fig. 2 and Fig. 3.

Table 3. Mechanical parameters of tested pastes measured for 1 day cured samples

\begin{tabular}{|c|c|c|c|}
\hline Material & $\begin{array}{c}\text { Bending } \\
\text { strength, MPa }\end{array}$ & $\begin{array}{c}\text { Compressive } \\
\text { strength, MPa }\end{array}$ & SAI, \% \\
\hline Pref & 2.3 & 7.5 & - \\
\hline P8 & 2.7 & 9.8 & 130.7 \\
\hline P16 & 2.4 & 8.8 & 117.3 \\
\hline P24 & 2.3 & 7.2 & 96.0 \\
\hline P32 & 2.3 & 6.5 & 86.7 \\
\hline P40 & 1.9 & 5.4 & 72.0 \\
\hline
\end{tabular}

Table 4. Mechanical parameters of tested pastes measured for 2 days cured samples

\begin{tabular}{|c|c|c|c|}
\hline Material & $\begin{array}{c}\text { Bending } \\
\text { strength, MPa }\end{array}$ & $\begin{array}{c}\text { Compressive } \\
\text { strength, MPa }\end{array}$ & SAI, \% \\
\hline Pref & 4.6 & 14.8 & - \\
\hline P8 & 5.3 & 20.3 & 137.2 \\
\hline P16 & 4.8 & 18.7 & 126.4 \\
\hline P24 & 4.7 & 15.3 & 103.4 \\
\hline P32 & 4.1 & 11.8 & 79.7 \\
\hline P40 & 3.7 & 10.9 & 73.7 \\
\hline
\end{tabular}

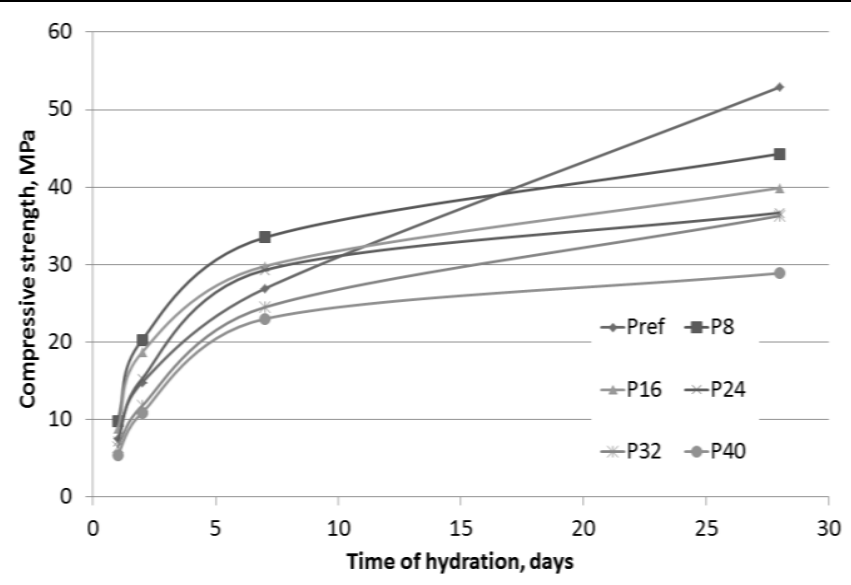

Fig. 2. Time dependent compressive strength

Table 5. Mechanical parameters of tested pastes measured for 7 days cured samples

\begin{tabular}{|c|c|c|c|}
\hline Material & $\begin{array}{c}\text { Bending } \\
\text { strength, MPa }\end{array}$ & $\begin{array}{c}\text { Compressive } \\
\text { strength, MPa }\end{array}$ & SAI, \% \\
\hline Pref & 7.9 & 26.9 & - \\
\hline P8 & 8.4 & 33.5 & 124.5 \\
\hline P16 & 8.1 & 29.8 & 110.8 \\
\hline P24 & 7.9 & 29.3 & 108.9 \\
\hline P32 & 7.3 & 24.5 & 91.1 \\
\hline P40 & 5.0 & 23.0 & 85.5 \\
\hline
\end{tabular}

Looking at the mechanical parameters development, we can observe slightly untypical behaviour of the tested blended binder. The contribution of the pozzolanic reaction to composite strength is usually developed at later curing stages, depending on the chemical and mineral composition of pozzolan and thus on its pozzolanic activity. In the large majority of blended cements, initial lower strength of hydration products can be observed compared to the pure Portland cement paste. For example O'Farrell et al. [17] investigated the effect of partial 
cement replacement by grounded bricks on cement based mortar compressive strength.

Table 6. Mechanical parameters of tested pastes measured for 28 days cured samples

\begin{tabular}{|c|c|c|c|}
\hline Material & $\begin{array}{c}\text { Bending } \\
\text { strength, MPa }\end{array}$ & $\begin{array}{c}\text { Compressive } \\
\text { strength, MPa }\end{array}$ & SAI, \% \\
\hline Pref & 10.1 & 52.9 & - \\
\hline P8 & 9.8 & 44.3 & 83.7 \\
\hline P16 & 9.1 & 39.9 & 75.4 \\
\hline P24 & 8.6 & 36.7 & 69.4 \\
\hline P32 & 8.4 & 36.3 & 68.6 \\
\hline P40 & 8.1 & 28.9 & 54.6 \\
\hline
\end{tabular}

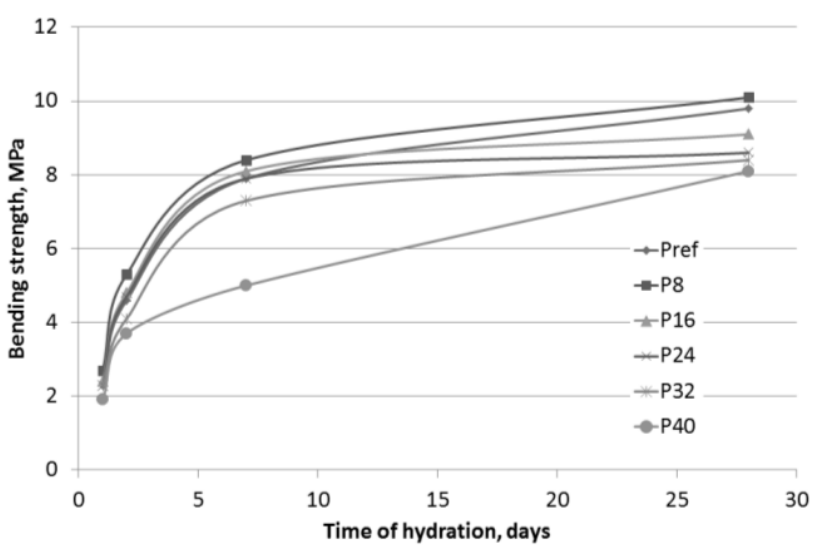

Fig. 3. Time dependent bending strength

They found that the presence of ground brick alters significantly the compressive strength of mortar and this is attributed to both the dilution effect and production of additional $\mathrm{C}-\mathrm{S}-\mathrm{H}$ gel from reaction of brick powder with calcium hydroxide $(\mathrm{CH})$. However, especially in the case of pozzolans finer than Portland cement, the filler effect can increase initially the amount of hydration products and thus their mechanical strength. Such results were published for example in $[18,19]$, where authors observed the acceleration of the hydration reactions depending on percentage of cement replacement. Similar behaviour we observed in the presented work. Here, the application of ceramic powder accelerated the formation of hydrated products up to 7 days of samples curing especially for materials P8, P16, and P24. At 28 days, the dilution effect was more significant and the obtained mechanical strengths were for reference mixture higher compared to other tested materials. For longer time of curing, one can expect improvement of mechanical properties of materials with incorporated ceramics due to the formation of C-S-H gels as results of pozzolanic reaction. Looking at the data obtained for 28 days cured samples, the most promising SAI was measured for P8, P16. Generally, all the tested mixtures exhibited sufficient mechanical strength, even in the case of a high level of cement replacement.

Basic physical properties of tested materials are given in Table 7. One can see slight increase of total open porosity values with increasing amount of incorporated pozzolan. However, looking at the compressive strength data for 28 days cured samples, the decrease of mechanical resistivity cannot be assigned to the increase of porosity only. Here, the filler effect of ceramic powder that contributes to low porosity of tested pastes even in case of high cement replacement was significant. Although the filler does not contribute significantly to the final paste strength, it improves its porosity and as given above, in the beginning of hydration reaction ensures the initial mechanical strength.

Table 7. Basic physical properties of studied materials

\begin{tabular}{|c|c|c|c|}
\hline Material & $\begin{array}{c}\text { Bulk density, } \\
\mathrm{kg} / \mathrm{m}^{3}\end{array}$ & $\begin{array}{c}\text { Matrix density, } \\
\mathrm{kg} / \mathrm{m}^{3}\end{array}$ & $\begin{array}{c}\text { Total open } \\
\text { porosity, } \%\end{array}$ \\
\hline Pref & 1600 & 2195 & 26.4 \\
\hline P8 & 1570 & 2165 & 27.5 \\
\hline P16 & 1580 & 2191 & 27.9 \\
\hline P24 & 1573 & 2204 & 28.6 \\
\hline P32 & 1538 & 2170 & 29.1 \\
\hline P40 & 1506 & 2179 & 30.9 \\
\hline
\end{tabular}

In Fig. 4-Fig. 7, there is given data on mercury intrusion porosimetry accessed for specific times of hydration. Here, the pore size distribution and incremental pore volume curves are given. The total porosity values measured as total intruded volume of mercury at maximum pressure are not presented, since these values can be affected by possible crushing of pore walls by mercury exerted pressures close to the material strength [20]. On this account, only pore diameters corresponding to the mercury pressures lower than measured compressive strength of particular pastes are presented.

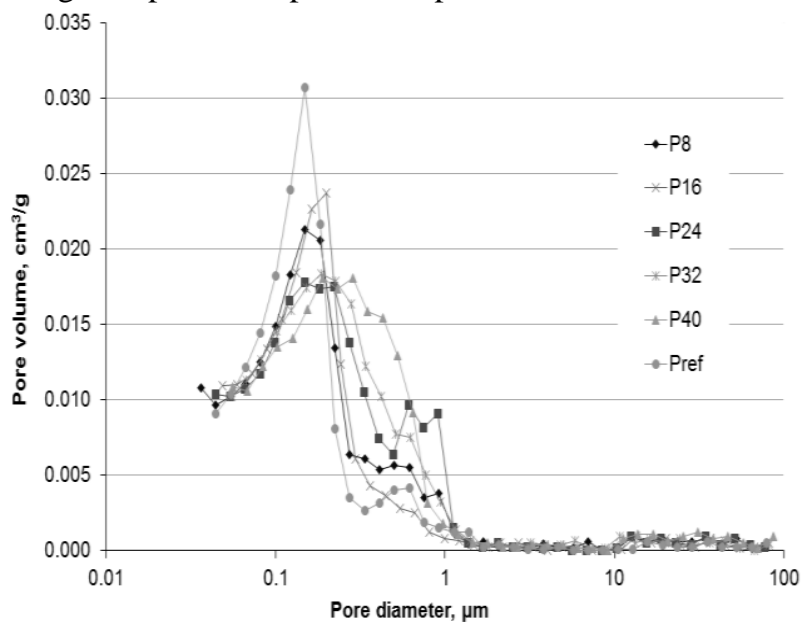

Fig. 4. Pore size distribution measured for 7 days cured samples

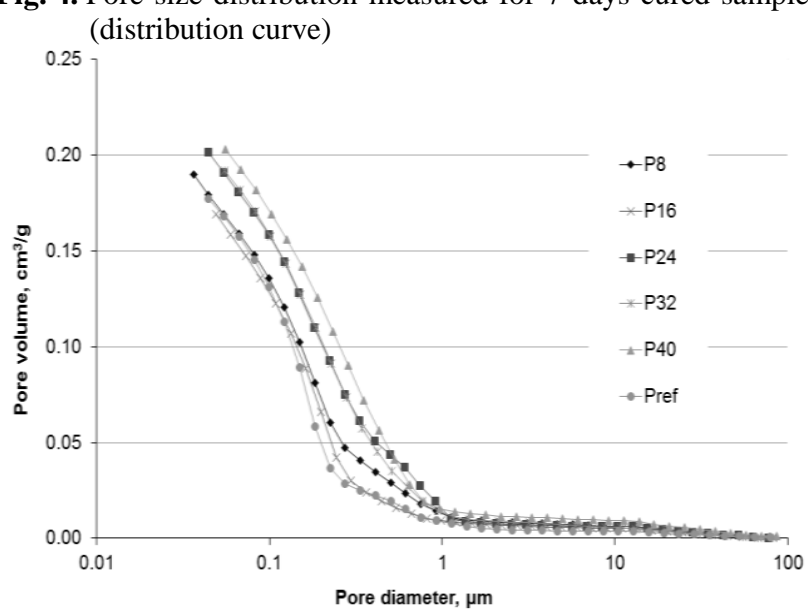

Fig. 5. Pore size distribution measured for 7 days cured samples (cumulative curve)

The pore diameters were calculated using Washburn equation: 
$d=\frac{-4 \sigma \cos \theta}{P}$,

where $\sigma$ is surface tension of mercury $\left(480 \times 10^{-3} \mathrm{~N} / \mathrm{m}\right)$ and $\theta$ is the contact angle between mercury and the pore wall.

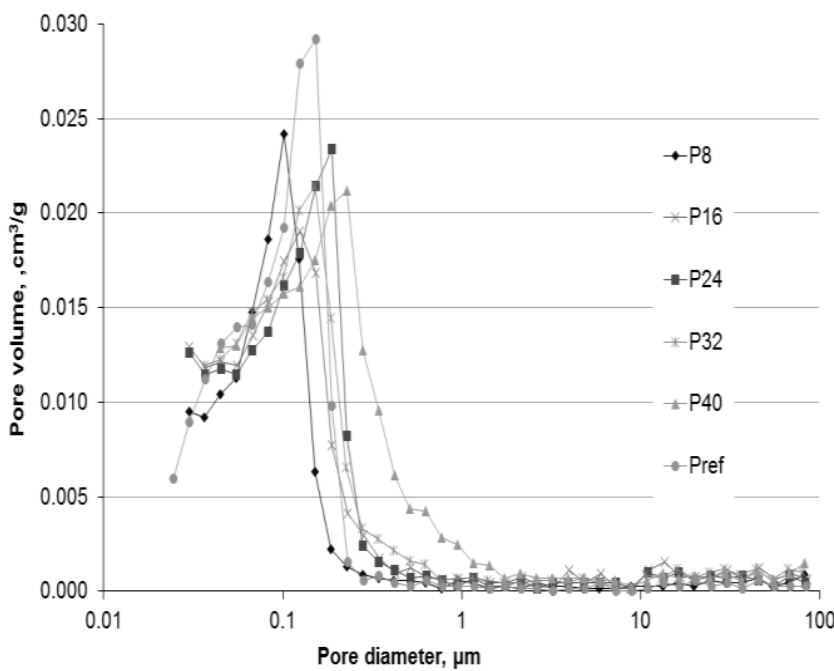

Fig. 6. Pore size distribution measured for 28 days cured samples (distribution curve)

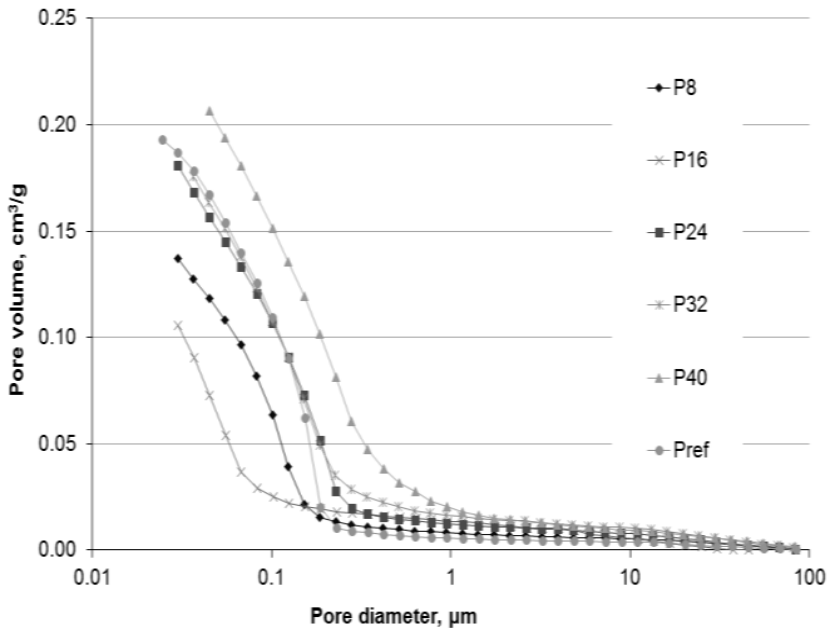

Fig. 7. Pore size distribution measured for 28 days cured samples (cumulative curve)

The contact angle is unknown, but is typically estimated between $120^{\circ}$ and $140^{\circ}$. In this study we used contact angle $130^{\circ}$. Beyond the assumed contact angle, the Washburn equation assumes cylindrical pores that are equally and entirely accessible to intruding mercury. As neither of these assumptions holds for the complex, interconnected pore network of cement-based materials, there has been considerable debate over the validity of mercury intrusion porosimetry-derived pore size distributions [21]. However, the assumption of cylindrical pores is a good middle ground for approximating the pores of paste, which vary in shape between rectangular and spherical.

The mercury intrusion porosimetry data is in good agreement with measured values of compressive and bending strength and corresponds also with data of basic physical parameters. Comparing the data obtained for 7 and 28 days of samples curing, the rate of hydration and formation of hydrated products can be recognized.
Typically, with increasing time of hydration the porosity and amount of bigger pores decreases, whereas this feature is visible for all studied pastes. With increasing amount of applied ceramics, the porosity increases, especially in the range of bigger pores having diameter $>0.25 \mu \mathrm{m}$.

Development of porous structure of researched pastes is demonstrated in Fig. 8 and Fig. 9. Here, the pore size distribution curves of paste P8 measured for 1, 7, and 28 days of hydration are presented. On can observe substantial changes in porous structure of researched paste depending on the hydration rate. Within the hydration process, the amount of bigger pores (pore diameter range $0.12-80 \mu \mathrm{m})$ decreases and on the contrary, the volume of smaller pores (pore diameter range $0.045-0.12 \mu \mathrm{m}$ ) increases. These data can be simply related to the mechanical parameters growth in time.

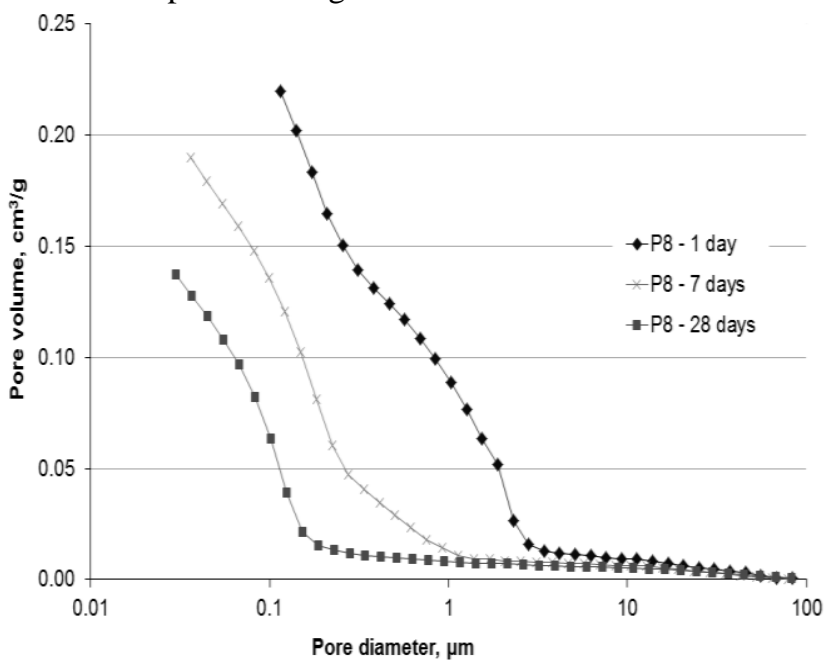

Fig. 8. Time dependent pore size distribution measured for paste

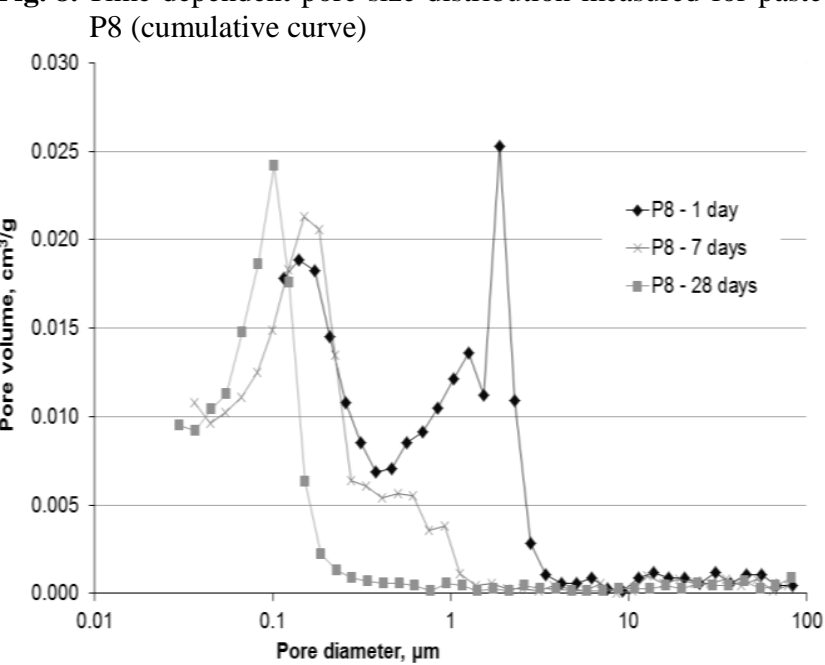

Fig. 9. Time dependent pore size distribution measured for paste P8 (cumulative curve)

\section{CONCLUSIONS}

The experimental analysis of possible usage of ceramic waste powder coming from brick grinding as partial Portland cement replacement in blended binder presented in this paper provided a detailed information on the development of mechanical parameters and formation of porous structure of tested pastes in dependence on hydration time and rate of cement substitution. The 
ceramics application in the blended Portland cement based binder in the amounts of 8 and $16 \%$ resulted in satisfactory mechanical properties and sufficient SAI of cement pastes what is very promising for future research. The perspective mechanical properties were obtained although the mineralogical composition and the content of amorphous phase were not optimal. It was found out that ceramic powder improved the strength development at early hydration stages, probably due to its action as a filler that reduced the assumed dilution effect. From the material research point of view, also other tested mixtures containing ceramic powder appeared as acceptable; this knowledge can be used, e.g., at the production of lowerstrength composites.

\section{Acknowledgement}

This research has been supported by the Czech Science Foundation, under project No. 14-04522S and by the Ministry of Education, Youth and Sport of the Czech Republic, under project No SGS14/174/OHK1/3T/11.

\section{REFERENCES}

1. Malhotra, V. M. Making Concrete Greener with Fly Ash Concrete International 21 (5) 1999: pp. 61-66.

2. Mehta, P. K. Reducing the Environment Impact of Concrete. Concrete Can Be Durable and Environmentally friendly Concrete International 10 2001: pp. 61-66.

3. Pacheco-Torgal, F., Jalali, S. Reusing Ceramic Wastes in Concrete Construction and Building Materials 24 2010: pp. $832-838$. http://dx.doi.org/10.1016/j.conbuildmat.2009.10.023

4. Glasser, F. P. Properties of Cement Waste Composites Waste management $16(1-3)$ 1996: pp. 159-168.

5. Keppert, M., $\quad$ Pavlik, Z., Tydlitat, V., $\quad$ Volfova, P., Svarcova, S., Syc, M., Cerny, R. Properties of Municipal Solid Waste Incineration Ashes with Respect to Their Separation Temperature Waste Management \& Research 30 (10) 2012: pp. $1041-1048$.

6. Keppert, M., Reiterman, P., Pavlik, Z., Pavlikova, M., Jerman, M., Cerny, R. Municipal Solid Waste Incineration Ashes and Their Potential for Partial Replacement of Portland Cement and Fine Aggregates in Concrete Cement Wapno Beton 15 (4) 2010: pp. 187-193.

7. Nath, P., Sarker, P.K. Effect of Mixture Proportions on the Drying Shrinkage and Permeation Properties of High Strength Concrete Containing Class F Fly Ash KSCE Journal of Civil Engineering 17 (6) 2013: pp. 1437-1445.

8. Atis, C.D. High Volume Fly Ash Abrasion Resistant Concrete Journal of Materials in Civil Engineering 14 2002: pp. 274-277. http://dx.doi.org/10.1061/(ASCE)0899-1561(2002)14:3(274)

9. Yildrim, K., Sümer, M. Effects of Sodium Chloride and Magnesium Sulfate Concentration on the Durability of
Cement Mortar with and without Fly Ash Composites Part B: Engineering 52 2013: pp. 56-61.

http://dx.doi.org/10.1016/j.compositesb.2013.03.040

10. Teng, S., Lim, T. Y. D., Divsholi, B. S. Durability and Mechanical Properties of High Strength Concrete Incorporating Ultra Fine Ground Granulated Blast-Furnace Slag Construction and Building Materials 40 2013: pp. 875-881. http://dx.doi.org/10.1016/j.conbuildmat.2012.11.052

11. Meyer, C. The Greening of the Concrete Industry Cement and Concrete Composites 31 2009: pp. 601-605. http://dx.doi.org/10.1016/j.cemconcomp.2008.12.010

12. Sabir, B. B., Wild, S., Bai, J. Metakaolin and Calcined Clays as Pozzolans for Concrete: a Review Cement and Concrete Composites 23 2001: pp. 441-454.

13. Pavlikova, M., Pavlik, Z., Keppert, M., Cerny, R. Salt Transport and Storage Parameters of Renovation Plasters and Their Possible Effects on Restored Buildings' Walls Construction and Building Materials 25 (3) 2011: pp. $1205-1212$. http://dx.doi.org/10.1016/j.conbuildmat.2010.09.034

14. Pavlík, Z., Trník, A., Ondruška, J., Keppert, M., Pavlíková, M., Volfová, P., Kaulich, V., Černý, R. Apparent Thermal Properties of Phase-Change Materials: An Analysis Using Differential Scanning Calorimetry and Impulse Method International Journal of Thermophysics 34 (5) 2013: pp. 851-864.

15. American Society for Testing and Materials, C $618-02$, Standard Specification for Coal Fly Ash and Raw or Calcined Natural Pozzolan for Use in Concrete.

16. American Society for Testing and Materials, ASTM C 311 02, Standard Test Methods for Sampling and Testing Fly Ash or Natural Pozzolans for Use in Portland-Cement Concrete.

17. O'Farrell, M., Wild, S., Sabir, S. S. Pore Size Distribution and Compressive Strength of Waste Clay Brick Mortar Cement and Concrete Composites 23 2001: pp. 81-91.

18. Bonavetti, V. L., Rahhal, V. F., Irassar, E. F. Evolution of the Hydration in Cements with Additions Materiales de Construcción 52 (268) 2002: pp. 57-64.

19. Rahhal, V., Talero, R. Effect of Three Natural Pozzolans in Portland Cement Hydration Materiales de Construcción 53 (269) 2003: pp. 29-40.

20. Panesar, D. K., Francis, J. Influence of Limestone and Slag on the Pore Structure of Cement Paste Based on Mercury Intrusion Porosimetry and Water Vapour Sorption Measurement Construction and Building Materials 52 2014: pp. $52-58$.

21. Chatterji, S. A. A Discussion of the Paper "Mercury Porosimetry - an Inappropriate Method for the Measurement of Pore Size Distributions in Cement-Based Materials" by S. Diamond Cement and Concrete Research 31 (11) 2001: pp. $1657-1658$.

http://dx.doi.org/10.1016/S0008-8846(01)00618-4 